\title{
Pathogens detected in the tick Haemaphysalis concinna in Western Poland: known and unknown threats
}

\author{
Dorota Dwużnik-Szarek ${ }^{1}$ (D) Ewa Julia Mierzejewska ${ }^{1}$. Mohammed Alsarraf ${ }^{1}$. \\ Mustafa Alsarraf ${ }^{1} \cdot$ Anna Bajer $^{1}$
}

Received: 13 March 2021 / Accepted: 22 July 2021 / Published online: 11 August 2021

(c) The Author(s) 2021

\begin{abstract}
In recent years, a new focus of the relict tick Haemaphysalis concinna was discovered in Western Poland, near Wolsztyn, Greater Poland voivodeship. This species may play an important role in the circulation of pathogens of medical and veterinary importance. In the present study we tested 880 juvenile ticks collected from rodents, including $427 \mathrm{H}$. concinna, 443 Ixodes ricinus and 10 Dermacentor reticulatus for three of the most common pathogens vectored by ticks in Poland: Rickettsia and Babesia spp. and Borrelia burgdorferi s.l. Additionally, molecular techniques were applied for accurate identification of tick host species (the voles Microtus and Alexandromys). Our study found differences in the range and prevalence of vectored pathogens between the three tick species. DNA of all three pathogens was found in I. ricinus. In juvenile H. concinna, DNA of Babesia microti, Borrelia afzelii and Rickettsia sp. was identified. Moreover, DNA of a new unnamed Babesia species related to B. crassa, was found in two $H$. concinna nymphs. This genotype of Babesia was previously identified in H. concinna in the Far East and then in Central Europe. DNA of Rickettsia raoulti and B. afzelii was detected in D. reticulatus nymphs. Among rodent hosts, Alexandromys oeconomus seems to be host of the highest significance for juvenile tick stages and was the only host species with $B$. afzelii detected in blood samples. Using phylogenetic methods, we confirmed a clear division between rodents from the genera Microtus and Alexandromys. Moreover, we found that A. oeconomus trapped in Western Poland clustered with a Central European A. oeconomus allopatric phylogroup.
\end{abstract}

Keywords Haemaphysalis concinna $\cdot$ Babesia sp. · Borrelia afzelii $\cdot$ Rickettsia sp. · Western Poland · Alexandromys oeconomus

Dorota Dwużnik-Szarek

dorota.dwuznik@biol.uw.edu.pl

1 Department of Eco-Epidemiology of Parasitic Diseases, Institute of Developmental Biology and Biomedical Sciences, Faculty of Biology, University of Warsaw, Miecznikowa 1, 02-096 Warsaw, Poland 


\section{Introduction}

The relict tick Haemaphysalis concinna occurs in Europe and Asia in isolated limited locations (Rubel et al. 2018). Together with Ixodes ricinus and Dermacentor reticulatus, $H$. concinna constitutes an important element of the ectoparasite community of domestic or free-living animals and humans (Duscher et al. 2013; Rubel et al. 2018). Adult ticks infest wildlife and farm animals (cattle, goats and sheep), larvae and nymphs feed on small rodents, birds or reptiles. Humans can be attacked by both nymphs and adult ticks (Rubel et al. 2018).

In Poland until 2018, only a single female of this species was found on a cow near Troszyn, in close proximity to the German-Polish border and the Baltic Sea shore, in West Pomerania in 1953 (Lachmajer et al. 1956). In 2018 several new foci of $H$. concinna were discovered in Western Poland (Dwużnik et al 2019a; Kiewra et al. 2019). In total, $43 \mathrm{H}$. concinna specimens were collected in six out of 24 monitored sites in Lower Silesia (dolnośląskie voivodeship) (Kiewra et al. 2019). Additionally, in summer 2018 all stages of $H$. concinna were collected from rodents and vegetation near Wolsztyn, in Greater Poland voivodeship (Dwużnik et al. 2019a).

Knowledge on pathogens vectored by $H$. concinna is still quite limited, likely due to the difficulties in collecting ticks, because of the limited geographical range and low tick density (Rubel et al. 2018). This tick species may act as a vector of the Rickettsia bacteria, etiological agents of TIBOLA/DEBONEL (tick-borne lymphadenopathy/Dermacentor spp.-borne necrosis-erythema-lymphadenopathy) (Rieg et al. 2011). Moreover, Borrelia burgdorferi s.l. was also detected in H. concinna (Rigo et al. 2011).

In recent years, we have completed a large project on the vector role of juvenile $D$. reticulatus obtained from rodents (Dwużnik et al. 2019a, b). Rodents play a pivotal role as the hosts for juvenile ticks, larvae and nymphs, of at least three important tick species (H. concinna, D. reticulatus and I. ricinus) (Dwużnik et al. 2019a, b). In the present study we assessed the possible role of $H$. concinna ticks as vectors of pathogens from the genera Rickettsia, Borrelia and Babesia. Because a tick species can carry multiple pathogens, we examined the vector specificity of three tick species collected from rodents $(H$. concinna, I. ricinus and $D$. reticulatus). Co-occurrence of pathogens was also investigated as co-feeding of different tick species on one host can contribute to cross-species pathogen transmission (Dwużnik et al. 2019b). Finally, we compared the detection of pathogen DNA in both juvenile ticks (H. concinna, I. ricinus, D. reticulatus) and their host individuals, to verify to which extent positive results obtained in molecular testing of ticks reflect infection of hosts, the source of tick blood meal (phenomenon of 'meal contamination') (Dwużnik et al. 2019b).

\section{Materials and methods}

All procedures involving rodent trapping and tick collection were described in detail in Dwużnik et al. (2019a, b). In total, 880 ticks belonging to three species were collected from 39 rodent hosts: 10 nymphs of $D$. reticulatus, 443 juvenile I. ricinus (405 larvae and 38 nymphs) and 427 juvenile $H$. concinna (405 larvae and 22 nymphs) (Table 1 ). Ticks were identified by a key (Estrada-Peńa et al. 2004) and by molecular methods 


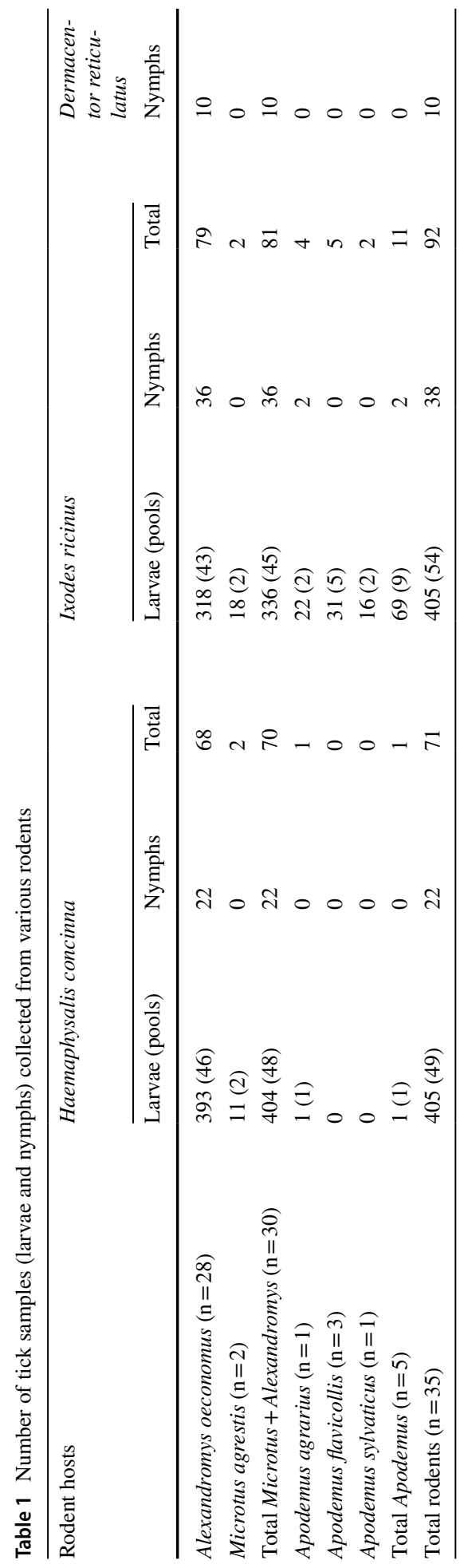


(Dwużnik et al. 2019a, b). Then, ticks were tested for the presence of DNA of three pathogens (Rickettsia spp., Babesia spp. and Borrelia burgdorferi s.1.).

Juvenile ticks, larvae and nymphs, were first subjected to DNA extraction. In order to increase the efficiency of molecular research, larvae of certain tick species were processed in pools, comprising 2-10 larvae from one host. Nymphs were processed individually. Genomic DNA was extracted from ticks/pools using Mini AX Tissue Spin DNA extraction kit (A\&A Biotechnology, Gdańsk, Poland) in accordance with the manufacturer's protocol.

For the detection of DNA of the Rickettsia, genus-specific primers CS409 (5'-CCTATG GCTATTATGCTTGC-3') and Rp1258 (5'-ATTGCAAAAAGTACAGTGAACA-3') were used for amplification of a $750 \mathrm{bp}$ fragment of the citrate synthase gene ( $g l t A$ ) (Roux et al. 1997) in modified condition as described by Kowalec et al. (2019).

For molecular screening of spirochaetes (B. burgdorferi s.l.) genus-specific primers: 132f/905r and 220f/824r (Wodecka et al. 2009) were used to amplify the bacterial flaB gene fragments (774 and 605 bp), respectively (Wodecka et al. 2009), in nested-PCR protocol in modified reaction conditions (Kowalec et al. 2017).

Nested-PCR targeting 18S rDNA was performed to detect DNA of Babesia spp. In the first reaction with the outer primers CRYPTO R/ CRYPTO F (Bonnet et al. 2007) a fragment of ca. $1200 \mathrm{bp}$ long was amplified. For the second reaction primers Bab GR2/ Bab GF2 were used to amplify a ca. $550 \mathrm{bp}$ fragment. DNA of Babesia canis was used as positive control. For both nested PCR protocols (for B. burgdorferi s.l. and Babesia spp.) $1.0 \mu 1$ of the first reaction product was used as the template DNA for the nested reactions.

All ticks tested in the present study had to be treated as partially engorged as they were collected from hosts. To compare occurrence of pathogen DNA in ticks and host samples, host samples (blood) were also tested for the presence of the pathogen DNA. DNeasy Blood \& Tissue Kit (Qiagen, USA) was used for extraction of genomic DNA from rodent blood samples. Identical PCR protocols as described for tick samples were used for testing of rodent samples.

To confirm correct classification of voles to the genera Microtus (M. arvalis, M. agrestis) and Alexandromys (A. oeconomus), amplification with primers L14729+H15906arvic (Lebedev et al. 2007) and sequencing of a $900 \mathrm{bp}$ fragment of $c y t B$ gene were applied on selected host samples as described in Lissovsky et al. (2018).

Reactions were performed in $20 \mu \mathrm{l}$ volume, including $1 \times$ PCR Dream Taq Green Buffer (Thermo Fisher Scientific Baltics UAB, Vilnius, Lithuania), 1U Dream Taq polymerase, $2 \mathrm{mM}$ dNTP, $1 \mu \mathrm{M}$ of each primer and $2 \mu \mathrm{l}$ of the extracted DNA sample. Negative controls were performed with $2 \mu \mathrm{l}$ of sterile water in the absence of template DNA. PCR products were visualized on 1.5\% agarose gel stained with Midori Green Stain (Nippon Genetics Europe, Düren, Germany).

Selected PCR products obtained from ticks and host blood were sequenced by a private company (Genomed, Warsaw, Poland). Sequence alignments and analyses were carried out using BLAST-NCBI and MEGA X software (Kumar et al. 2018). Phylogenetic analyses were performed using the maximum likelihood method of tree-construction. The evolutionary model was chosen in accordance to the data (following implemented model test in MEGA X) and bootstrapped over 1000 randomly generated sample trees. Identical sequences obtained in the study were pooled for analysis. In case of Borrelia spp., the evolutionary history was inferred by using the maximum likelihood method and HasegawaKishino-Yano model (Hasegawa et al. 1985). For Babesia sp. analyses, the evolutionary history was inferred by using the maximum likelihood method and Kimura 2-parameter model (Kimura, 1980). For the $c y t B$ gene fragment from rodents, the evolutionary history was inferred by using the maximum likelihood method and Hasegawa-Kishino-Yano 
model. For each analysis, initial tree(s) for the heuristic search were obtained automatically by applying Neighbor-Join and BioNJ algorithms to a matrix of pairwise distances estimated using the Maximum Composite Likelihood (MCL) approach, and then selecting the topology with superior log likelihood value. Additionally, phylogenetic analysis was performed with the Neighbor Joining and Minimum Evolutionary methods, and tree topologies were compared for a robust phylogeny (supplementary files).

\section{Statistical analysis}

For the analysis of prevalence (\% PCR-positive samples), we applied maximum likelihood techniques based on log linear analysis of contingency tables in the IBM SPSS v.21 software package. Factors such as: tick species (3 levels: H. concinna, I. ricinus, D. reticulatus), host genus [2 levels: Apodemus combined (A. agrarius, A. flavicollis, A. sylvaticus), Microtus +Alexandromys combined (A. oeconomus, M. agrestis)], and-only for nymphs - co-infections ( 3 levels: 0 , lack of pathogen; 1 , one pathogen; 2 , two or three pathogens detected in a tick) were used in models with the presence or absence of pathogen DNA considered as a binary factor $(0,1)$. For each level of analysis in turn, beginning with the most complex model, involving all possible main effects and interactions, those combinations that did not contribute significantly to explaining variation in the data were eliminated in a stepwise fashion beginning with the highest level interaction (backward selection procedure). A minimum sufficient model was then obtained, for which the likelihood ratio of $\chi^{2}$ was not significant, indicating that the model was sufficient in explaining the data (Behnke et al. 2001; Bajer et al. 2005).

\section{Ethical statement}

All of the procedures conducted on rodents were approved by the First Warsaw Local Ethics Committee for Animal Experimentation in Poland (ethical license number: 706/2015).

\section{Results}

In total, $71 \mathrm{H}$. concinna samples (22 nymphs and 49 pools of larvae), 92 I. ricinus samples (38 nymphs and 54 pools of larvae) and 10 nymphs of $D$. reticulatus were screened for the presence of pathogens. The structure of the samples from certain host species is shown in Table 1.

The overall detection (\% positive) of specific pathogen DNA in all samples (larvae pools + nymphs) differed between the examined tick species. DNA of Rickettsia spp. was found in four D. reticulatus nymphs, in $31.5 \%$ of I. ricinus samples $(72.4 \%$ of larvae pools, $27.6 \%$ of nymphs), and the lowest prevalence was found in $H$. concinna (2.9\%; only in two larvae pools) (Rickettsia spp. presence/absence $\times$ tick species: $\chi^{2}=23.26$, d.f. $=2$, $P<0.001)$.

DNA of B. burgdorferi s.l. was detected in $67.4 \%$ of $I$. ricinus samples $(64.8 \%$ of larvae pools, $71.7 \%$ of nymphs), in almost $40 \%$ of $H$. concinna ( $51 \%$ of larvae pools, $13.6 \%$ of nymphs) and in one $D$. reticulatus nymph (B. burgdorferi s.l. presence/absence $\times$ tick species: $\chi^{2}=33.17$, d.f. $\left.=2, P<0.001\right)$.

DNA of Babesia spp. was identified in more than $40 \%$ of I. ricinus samples $(57.4 \%$ of larvae pools, $18.4 \%$ of nymphs) and in $7 \%$ of $H$. concinna samples $(6.1 \%$ of larvae 
pools, $9.1 \%$ of nymphs) (Babesia spp. presence/absence $\times$ tick species: $\chi^{2}=33.10$, d.f. $=2$, $P<0.001)$.

\section{Influence of host species/genus on pathogen detection in feeding ticks}

\section{Haemaphysalis concinna}

Although H. concinna ticks were collected both from voles (Microtus and Alexandromys) and mice (Apodemus), pathogen DNA was detected only in $H$. concinna obtained from voles. In ticks collected from A. oeconomus, DNA of Rickettsia spp., B. burgdorferi s.1. and Babesia spp. was detected (in 2.9, 38.2 and 7.4\% of samples, respectively). Borrelia burgdorferi-positive samples were also found in a few ticks collected from $M$. agrestis.

\section{Ixodes ricinus}

A similar prevalence of Rickettsia spp. positive samples was found in ticks collected from Apodemus spp. and Microtus + Alexandromys (36.4 and 30.9\%, respectively). DNA of Rickettsia was detected in $31.6 \%$ samples of ticks collected from A. oeconomus and from two species of mice: A. agrarius (25\% positive) and A. flavicollis (60\% positive) (percentages were not significantly different).

The percentage of B. burgdorferi-positive samples in I. ricinus ticks was high, regardless of the rodent species from which ticks were collected $(69.1 \%$ in tick samples from Microtus + Alexandromys, $54.6 \%$ in tick samples from Apodemus spp.). The DNA of $B$. burgdorferi s.l. was detected in all samples of ticks collected from the striped field mouse, A. agrarius. One B. burgdorferi-positive sample was found in ticks collected from the field voles $M$. agrestis, and two from yellow necked mice, A. flavicollis.

DNA of Babesia spp. was found in ticks collected from both voles (genera Microtus + Alexandromys) and Apodemus spp.; however, only in $9.1 \%$ of I. ricinus collected from mice and in $45.7 \%$ of ticks collected from voles (percentages not significantly different). Similar high percentages of Babesia-positive samples were detected in ticks collected from A. oeconomus (45.6\%), M. agrestis (one sample, 50\%) and in one sample also from $A$. flavicollis (20\%) (percentages not significantly different). DNA of Babesia spp. was not detected in ticks obtained from A. agrarius and A. sylvaticus.

Among 10 D. reticulatus nymphs collected from A. oeconomus, one was positive for Rickettsia spp. and four for B. burgdorferi s.l.

\section{Molecular detection of pathogen DNA in rodents}

Host species had no significant effect on the prevalence of Babesia infection in rodents; however, 33.1\% (nine individuals) of A. oeconomus, one M. agrestis and one A. flavicollis were Babesia-positive. Apodemus agrarius and A. sylvaticus tested negative for Babesia infection. Alexandromys oeconomus was the only rodent species in which DNA of B. burgdorferi s.1. was detected in blood (in $17.9 \%$, five individuals). DNA of Rickettsia was not detected in rodent blood samples. 


\section{Detection of pathogen DNA in ticks from infected and non-infected rodents}

Host infection status had an effect on detection of $B$. burdorferi s.l. in ticks depending on tick stadium (B. burgdorferi s.l. tick infection $\times$ host infection $\times$ tick stadium: $\chi^{2}=8.45$, d.f. $\left.=1, \mathrm{P}=0.01\right)$. DNA of $B$. burgdorferi $\mathrm{s} .1$ was detected in $34.1 \%$ of nymphs and $65.9 \%$ of larvae pools collected from Borrelia-positive rodents, in comparison with $47.6 \%$ of nymphs and $52.4 \%$ of larvae collected from Borrelia-negative rodents.

Most larvae pools obtained from Babesia-infected rodents were positive $(79.1 \%)$ compared with $53.1 \%$ of positive larvae pools collected from uninfected hosts (percentages not significantly different). However, DNA of $B$. microti was detected in $46.9 \%$ of nymphs collected from $B$. microti-negative rodents and in $20.9 \%$ of nymphs collected from $B$. microti-positive rodents.

\section{Co-infections in nymphs}

Altogether, DNA of one pathogen species was detected in 22.7, 60.5 and $50 \%$ of $H$. concinna, I. ricinus and D. reticulatus nymphs, respectively. Co-infections of two and three pathogens were found in $23.7 \%$ of I. ricinus nymphs. No co-infections were detected in $H$. concinna nor in $D$. reticulatus nymphs (tick species $\times$ co-infections: $\chi^{2}=29.25$, d.f. $\left.=1, P<0.001\right)$.

\section{Molecular identification of pathogen species/genotypes}

Twenty-two Borrelia-positive PCR products were sequenced: 11 from H. concinna (from two nymphs and nine larvae pools; $39.4 \%$ of 28 positive samples), nine from $I$. ricinus (one larvae pool and eight nymphs; $14.5 \%$ of 62 positive samples) and two from A. oeconomus voles. All sequences displayed the highest identity (99-100\%) to Borrelia afzelii (GenBank accession number KX646195). The phylogenetic tree, incorporating 17 sequences obtained in this study and 19 reference sequences from GenBank, is presented in Fig. 1. The tree topology showed that sequences obtained from two tick species and voles clustered on one separate branch, as expected from BLAST analysis, constituting the $B$. afzelii clade. Trees constructed using Minimum Evolutionary and Neighbor Joining models showed similar topology to the maximum likelihood analysis (Supplementary file 1).

Nine Babesia spp. PCR products from I. ricinus larvae pools $(23.7 \%$ of 28 positive samples) and four Babesia spp. PCR products from $H$. concinna (one nymph and three larvae pools; $80 \%$ of five samples) were successfully sequenced. Eleven obtained sequences (all from $I$. ricinus and two from $H$. concinna) were essentially identical (identity above $99.9 \%$ ) to the sequence of B. microti Jena genotype (EF413181). However, two Babesia sequences obtained from $H$. concinna displayed the highest similarity (97.4 and 100\%, respectively) to undescribed Babesia species from H. concinna, Russia (KJ486560) and only $93.7 \%$ identity with B. microti (KC821597).

A representative tree for $18 \mathrm{~S}$ rDNA sequences, obtained using the maximum likelihood method and a Kimura 2-parameter model is presented in Fig. 2. Our B. microti sequences from $I$. ricinus and $H$. concinna grouped together with numerous $B$. microti zoonotic isolates from ticks, rodents and humans (Fig. 2). Two unidentified Babesia sequences from $H$. concinna grouped separately with a few undescribed Babesia 


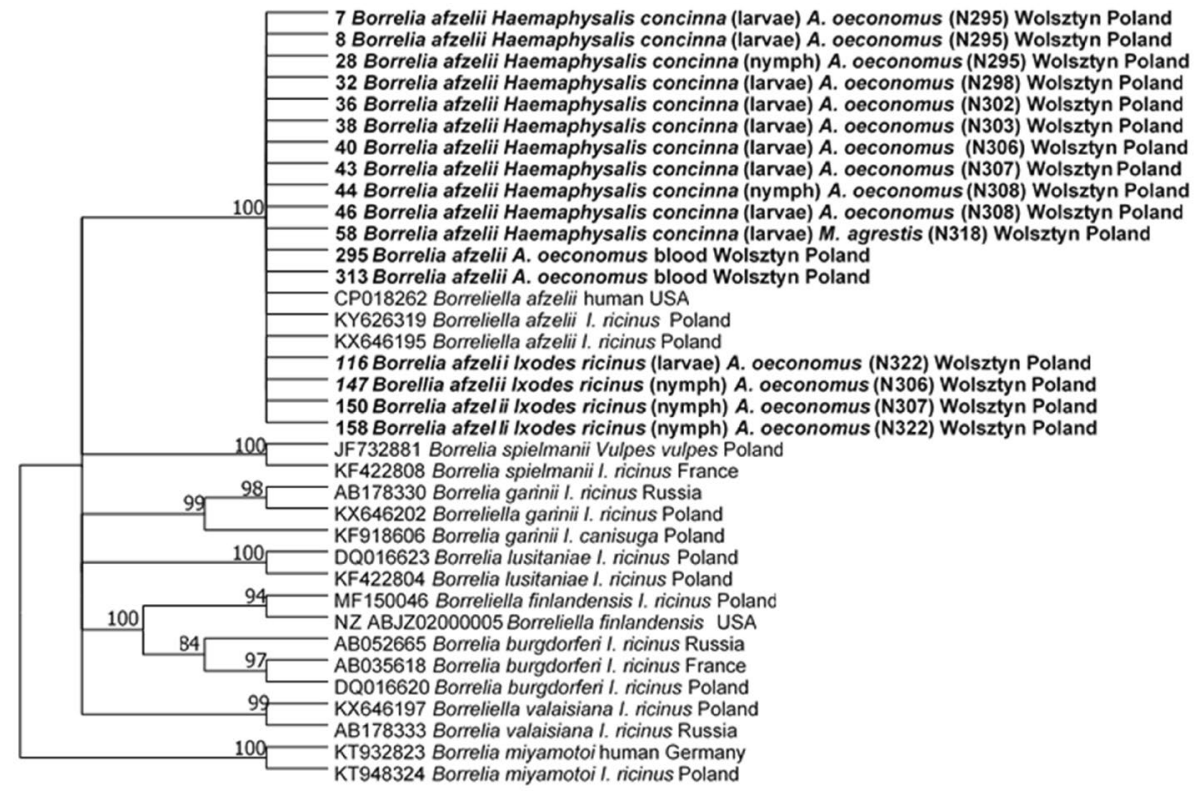

Fig. 1 Molecular phylogenetic analysis of flaB of Borelia burgdorferi s.l. (605 bp), showing the tree with the highest $\log$ likelihood $(-1677.91)$. The percentage of trees in which the associated taxa clustered together is shown next to the branches. This analysis involved 36 nucleotide sequences. All positions containing gaps and missing data were eliminated (complete deletion option). In total, there were 529 positions in the final dataset

sequences from I. persulcatus and H. concinna from Russia (Rar et al. 2014) and China (Fig. 2). Interestingly, this group of sequences was the most similar (sister group) to ovine piroplasm B. crassa (95.7\% similarity) and to B. crassa-like group pathogenic for humans (Jia et al. 2018). Trees constructed using Minimum Evolutionary and Neighbor Joining models showed similar topology to the maximum likelihood analysis (Supplementary file 2).

For Rickettsia spp. only three sequences of the 750-bp fragment of the citrate synthase gene $(g l t A)$ were obtained. Two Rickettsia sequences from I. ricinus (one larvae pool and one nymph) displayed the highest identity (99.6 and 97.5\%, respectively) with $R$. helvetica from I. ricinus from Serbia (MH618386). A sequence from a D. reticulatus nymph was identified as $R$. raoulti (99.4\% similarity to sequences MN388798 (from Carios vespertilionis, China), MT178334 (from Dermacentor nuttalli, China) and KU310589 (from D. reticulatus, Russia). Sequencing of Rickettsia PCR products from H. concinna was unsuccessful.

\section{Molecular identification of rodent species}

Eleven of 16 positive PCR products (900 bp cytB fragment) were sequenced for differentiation of Microtus and Alexandromys voles. Nine sequences from A. oeconomus displayed the highest identity (98.2-99.7\%) with sequence AY220010 representing M. oeconomus (A. oeconomus) from Poland and clustered with a Central European A. oeconomus allopatric phylogroup (Brunhoff et al. 2003; Galbreath and Cook, 2004; Iwasa et al. 2009) 


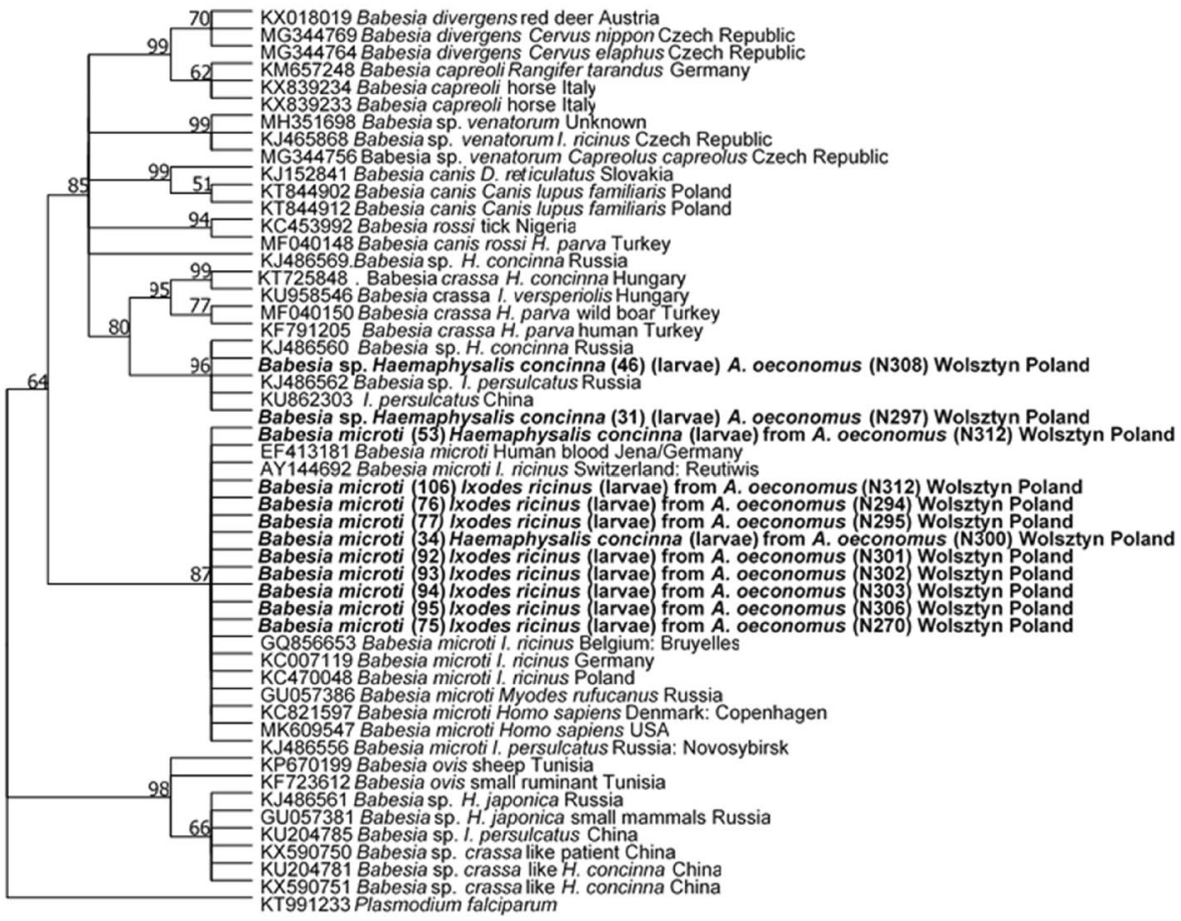

Fig. 2 Molecular phylogenetic analysis of $18 \mathrm{~S}$ rDNA of Babesia spp. (550 bp), showing the tree with the highest log likelihood $(-2819.70)$. The percentage of trees in which the associated taxa clustered together is shown next to the branches. A discrete Gamma distribution was used to model evolutionary rate differences among sites [five categories $(+G$, parameter $=2.1193)$ ]. This analysis involved 52 nucleotide sequences. In total, there were 462 positions in the final dataset

(Fig. 3). Two sequences were the most similar (99.0-99.9\%) to M. agrestis from Poland (KF218938). Trees constructed using Minimum Evolutionary and Neighbor Joining models showed similar topology to the maximum likelihood analysis (Supplementary file 3).

\section{Discussion}

Present study revealed that DNA of three tick-borne pathogens-Babesia, B. burgdorferi s.l. and Rickettsia spp.- - can be detected in high percentage of juvenile ticks feeding on rodents, thus confirming the pivotal role of rodents as the source of blood meal and/or infection for three species of ticks. Present study provided also the first results on the detection of the pathogen DNA in juvenile H. concinna ticks from the area of Poland. Additionally, A. oeconomus seems to be the host of the highest significance, due to high prevalence of Babesia and Borrelia either in ticks collected from this host species or in hosts themselves. One of the most important findings is the detection of new (undescribed) Babesia species in H. concinna, similar to Babesia found in the Far East (Russia and China) and Slovakia related to $B$. crassa, probably representing species of piroplasm specific for $H$. concinna. 


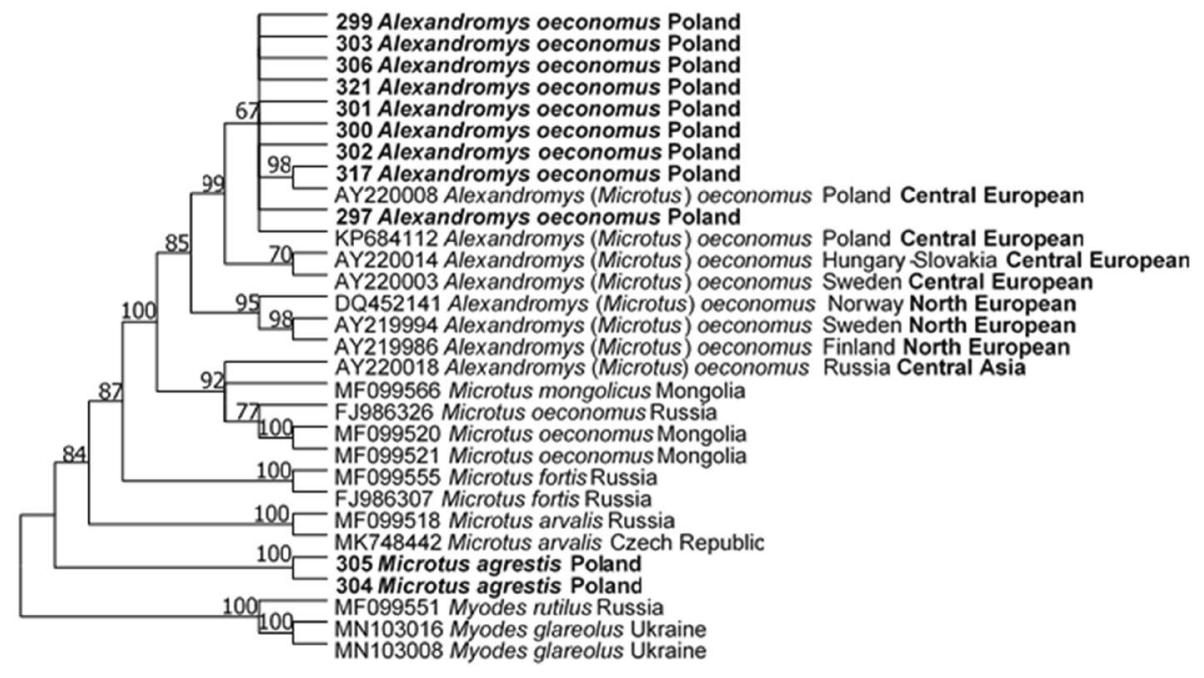

Fig. 3 Molecular phylogenetic analysis of $c y t B$ gene $(900 \mathrm{bp})$, showing the tree with the highest log likelihood (-3109.99). The percentage of trees in which the associated taxa clustered together is shown next to the branches. This analysis involved 30 nucleotide sequences. In total, there were 871 positions in the final dataset

In the present study, substantial numbers of juvenile $I$. ricinus (about 440) and $H$. concinna (427) ticks were tested and DNA of all three tick-borne pathogens was identified both in larvae pools and in nymphs of both species. Among $10 \mathrm{D}$. reticulatus, only five were positive (one for B. afzelii, four for Rickettsia [ $2 \times R$. raoulti]).

Among juvenile $H$. concinna and I. ricinus feeding on rodents, the most common pathogen was B. burgdorferi s.l. (mostly B. afzelii) found in almost $40 \%$ of $H$. concinna and $67 \%$ of $I$. ricinus. Interestingly, DNA of B. burgdorferi s.l. was found not only in ticks collected form positive rodents but also in ticks collected from negative hosts, and from hosts representing different genera (Apodemus, Alexandromys and Microtus). However, we tested rodent blood samples for Borrelia presence, and occurrence of $B$. burgdorferi in blood can be short in comparison to its persistence in other host tissues (Liang et al. 2020)—some positive rodents could have tested false negative based on blood samples. Taking into account the high percentage of B. burgdorferi-positive ticks, and especially high prevalence in $I$. ricinus nymphs and $H$. concinna larvae, we may conclude that this is the most common tick-transmitted pathogen circulating between ticks and rodents, and possessing the highest public health threat. Thus, this is the first study to demonstrate that also $H$. concinna ticks feeding on infected rodents may play a role as vectors of $B$. burgdorferi s.l., particularly for B. afzelii (all sequenced PCR products were $B$. afzelii). There is limited data on spirochaetes detection in H. concinna. DNA of B. afzelii was detected in H. concinna nymphs in Hungary (Rigo et al. 2011). Two Borrelia species were detected in adult ticks: $B$. garinii in un-fed, host-seeking $H$. concinna from southeastern China (Chu et al. 2008) and B. miyamotoi in one from 36 examined $H$. concinna in northeastern China (Jiang et al. 2018). From Far East Russia, only 14 of 481 examined $H$. concinna ticks were B. burgdorferi s.l.-positive (Pukhovskaya et al. 2019). However, in many other studies $H$. concinna ticks collected from 
vegetation or rodents (Central Europe and China) tested negative for Borrelia infections (Kahl et al. 1992; Blaschitz et al. 2008; Wang et al. 2019; Heglasová et al. 2020).

Our result (67.4\% of positive samples of B. burgdorferi s.1. in I. ricinus instars) was definitely higher than prevalence of Borrelia spp. in I. ricinus questing ticks examined in other studies in Poland. Prevalence of B. burgdorferi s.l. in questing adult I. ricinus was about $12 \%$ in urban parks in Warsaw, as well as in natural forests near Białowieża (Kowalec et al. 2017). In northeastern Poland, prevalence of B. burgdorferi s.l. was about $13 \%$ in questing I. ricinus nymphs (Kubiak et al. 2019) and almost $45 \%$ in pooled unfed nymphs in Lower Silesia, western Poland (Kiewra et al. 2014).

The second most abundant pathogen was Rickettsia-about $28 \%$ of juvenile $H$. concinna and $31 \%$ of juvenile I. ricinus ticks tested positive (and four out of 10 D. reticulatus, $40 \%$ ). A similar and high percentage of detection of Rickettsia spp. DNA in ticks regardless of the tick species and stadium, or host species from which ticks were collected, is in agreement with the endosymbiont status of these bacteria in ticks (circulating in tick populations, independent on external sources of infection; Parola et al. 2013). Genotyping revealed the presence of typical tick-specific species: $R$. raoultii in $D$. reticulatus and $R$. helvetica in $I$. ricinus (Chmielewski et al. 2009; Stańczak et al. 2016; Kowalec et al. 2019); unfortunately, species of Rickettsia from $H$. concinna could not be determined (unsuccessful sequencing). No Rickettsia DNA was found in rodents. There are not enough data on vertebrates as a reservoir of these bacteria (Tomassone et al. 2018) and the role of rodents as a source of these pathogens needs more attention.

Although Babesia infection was quite common among three host species (17-40\% in $A$. flavicollis, A. eoconomus and M. agrestis), detection of this parasite's DNA differed profoundly between tick species: it was not detected in the $10 \mathrm{D}$. reticulatus, but was detected in about $7 \%$ of $H$. concinna and in $41 \%$ (18\% nymphs and $57 \%$ larvae pools) of I. ricinus. Apparently, detection of $B$. microti in ticks, tick hosts and rodents, was highly associated: up to $80 \%$ of $I$. ricinus larvae pools originated from infected rodents (A. oeconomus, $A$. flavicollis and $M$. agrestis) tested positive. However, we obtained reversed relationship with the percentage of Babesia-infected I. ricinus nymphs: twice higher in nymphs collected from negative rodents than from positive ones. Nevertheless, B. microti is abundant among rodents, especially voles (Karbowiak et al. 2005; Tołkacz et al. 2017; Dwużnik et al. 2019b) and surely voles are the main source of infections for juvenile ticks feeding on them. The presence of DNA of a zoonotic strain of $B$. microti in $H$. concinna is a novel finding (Zhou et al. 2014); however, the vector competence of $H$. concinna for this Babesia species must be verified in experimental transmission studies (Gray et al. 2019) before a final conclusion can be drawn.

The new Babesia species seems to be quite specific for $H$. concinna because this genotype was found in this tick species both in Central Europe-in Poland (present study), Slovakia (Hamšíková et al. 2016), Hungary (Flaisz et al. 2017)—and in the Far East in Russia (Rar et al. 2014), although it was also found in I. persulcatus in China (Rar et al. 2014). Interestingly, in China B. crassa-like, which was found in H. concinna ticks, was also pathogenic for humans (Jia et al. 2018). High similarity of Babesia sp. found in the current study to the abovementioned B. crassa-like from humans and H. concinna in China (phylogenetic trees) brings attention to pathogenic potential of this Babesia species-a possible new health threat in Central Europe.

Rodent species trapped in our study have a wide geographical range and occur commonly in Eurasia, including the western region of Poland. They are abundant in various habitats (natural, urban, semi-urban; Apodemus spp.), in fallow land, wetland, river basin (Alexandromys, Microtus) (Lubicz-Niezawitowski 1933; Paziewska et al. 2010; 
Gortat et al. 2014; Dwuznik et al. 2017; Welc-Faleciak et al. 2008). After molecular and phylogenetic analyses, we can confirm the new taxonomic status of the root vole $A$. oeconomus, previously a subgenus of Microtus, now elevated to full generic rank (Lissovsky and Obolenskaya 2011; Lissovsky et al. 2018; Zorenko and Atanasov 2018). Phylogenetic analysis confirmed not only the division between Microtus and Alexandromys, but also separated the allopatric phylogroups among A. oeconomus species (Brunhoff et al. 2003; Galbreath and Cook, 2004; Iwasa et al. 2009).

Alexandromys oeconomus is apparently a very important host for all three tick species and $B$. afzelii and B. microti pathogens. To our best knowledge, this is a first report of juvenile $H$. concinna feeding on $A$. oeconomus. Juvenile $H$. concinna were previously collected from medium size mammals, like roe deer, goats and sheep (Hornok et al. 2016), birds (Flaisz et al. 2017), European ground squirrel, Spermophilus citellus (Radulović et al. 2017) and even lizards (Avila and Morando 2003). However, data on rodents as the host species for $H$. concinna are scarce (Dwużnik et al. 2019a; Heglasová et al. 2020). Haemaphysalis concinna is still considered a rare tick species, occurring in isolated limited locations, so any new data on hosts for juvenile stages uncover new knowledge on their host reservoir and the possibility of pathogens circulation.

\section{Conclusions}

Our study showed differences in prevalence of various pathogens between three tick species. For the first time in Poland we detected a new species of Babesia sp. specific to $H$. concinna. Full identification of the new, unnamed Babesia species (host reservoir, pathogenicity, microbiological assessment, geographical range, etc.) needs further investigation. Also, we highlighted that morphological features may not be sufficient for correct identification of rodents from Alexandromys and Microtus genera.

Supplementary Information The online version contains supplementary material available at https://doi. org/10.1007/s10493-021-00647-x.

Authors' contributions DDS: conceptualization, data collection, laboratory and field studies, statistical and phylogenetic analysis, drafting the manuscript, project funding; EJM: data collection and field studies; MA, MA: help with phylogenetic analysis; AB: conceptualization, project funding, supervision. All authors read and approved the final manuscript.

Funding The study was funded by the National Science Centre (NCN) Sonata Bis Grant No. 2014/14/E/ NZ7/00153 (AB) and by the Ministry of Science and Higher Education through the Faculty of Biology, University of Warsaw intramural Grant DSM No. 501-D114-01-1140500 (DDS).

Data availability All data generated or analysed during this study are included in this published article.

\section{Declarations}

Conflict of interest The authors declare that they have no competing interests.

Ethical approval All of the procedures conducted on rodents were approved by the First Warsaw Local Ethics Committee for Animal Experimentation in Poland (Ethical License Number: 706/2015).

Research involving human participants This article does not contain any studies with human participants. 
Open Access This article is licensed under a Creative Commons Attribution 4.0 International License, which permits use, sharing, adaptation, distribution and reproduction in any medium or format, as long as you give appropriate credit to the original author(s) and the source, provide a link to the Creative Commons licence, and indicate if changes were made. The images or other third party material in this article are included in the article's Creative Commons licence, unless indicated otherwise in a credit line to the material. If material is not included in the article's Creative Commons licence and your intended use is not permitted by statutory regulation or exceeds the permitted use, you will need to obtain permission directly from the copyright holder. To view a copy of this licence, visit http://creativecommons.org/licenses/by/4.0/.

\section{References}

Avila LJ, Morando M (2003) Ectoparasite of lizards and possible vector: the mammal hard tick Haemaphysalis concinna KOCH, 1844. Herpetozoa 16:86-88

Bajer A, Behnke JM, Pawelczyk A, Kuliś-Małkowska K, Sereda MJ, Siński E (2005) Medium-term temporal stability of the helminth component community structure in bank voles (Clethrionomys glareolus) from the Mazury Lake District region of Poland. Parasitology 130:213-228

Behnke JM, Barnard CJ, Bajer A, Bray D, Dinmore J, Frake K, Osmond J, Race T, Sinski E (2001) Variation in the helminth community structure in bank voles (Clethrionomys glareolus) from three comparable localities in the Mazury Lake district region of Poland. Parasitology 123:401-414

Blaschitz M, Narodoslavsky-Gföller M, Kanzler M, Walochnik J, Stanek G (2008) Borrelia burgdorferi sensu lato genospecies in questing Ixodes ricinus ticks in Austria. Int J Med Microbiol 298:168-176

Bonnet S, Jouglin M, L'Hostis M, Chauvin A (2007) Babesia sp. EU1 from roe deer and transmission within Ixodes ricinus. Emerg Infect Dis 13:1208-1210

Brunhoff C, Galbreath KE, Fedorov V, Cook JA, Jaarola M (2003) Holarctic phylogeography of the root vole (Microtus oeconomus): implications for late Quaternary biogeography of high latitudes. Mol Ecol 12:957-968

Chmielewski T, Podsiadly E, Karbowiak G, Tylewska-Wierzbanowska S (2009) Rickettsia spp. in ticks, Poland. Emerg Infect Dis 15:486-488

Chu CY, Jiang BG, Liu W, Zhao QM, Wu XM, Zhang PH, Zhan L, Yang H, Cao WC (2008) Presence of pathogenic Borrelia burgdorferi sensu lato in ticks and rodents in Zhejiang, south-east China. J Med Microbiol 57:980-985

Duscher GG, Feiler A, Leschnik M, Joachim A (2013) Seasonal and spatial distribution of ixodid tick species feeding on naturally infested dogs from Eastern Austria and the influence of acaricides/repellents on these parameters. Parasites Vectors 6:76

Dwużnik D, Gortat T, Behnke JM, Gryczyńska A, Bednarska M, Mikoszewski AS, Kozakiewicz M, Bajer A (2017) Comparison of helminth community of Apodemus agrarius and Apodemus flavicollis between urban and suburban populations of mice. Parasitol Res 116:2995-3006

Dwużnik D, Mierzejewska EJ, Drabik P, Kloch A, Alsarraf M, Behnke JM, Bajer A (2019a) The role of juvenile Dermacentor reticulatus ticks as vectors of microorganisms and the problem of "meal contamination.” Exp Appl Acarol 78:181-202

Dwużnik D, Mierzejewska EM, Alsarraf M, Bajer A (2019b) A new focus of the tick Haemaphysalis concinna in Western Poland. Exp Appl Acarol 78:93-112

Estrada-Peña A, Bouattour A, Camicas J-L, Walker AR (2004) Ticks of domestic animals in the Medi terranean region: a guide to identifcation of species. University of Zaragoza, Saragossa

Felsenstein J (1985) Confidence limits on phylogenies: an approach using the bootstrap. Evolution 39:783-791

Flaisz B, Sulyok KM, Kováts D, Kontschán J, Csörgő T, Csipak Á, Gyuranecz M, Hornok S (2017) Babesia genotypes in Haemaphysalis concinna collected from birds in Hungary reflect phylogeographic connections with Siberia and the Far East. Ticks Tick Borne Dis 8:666-670

Galbreath KE, Cook JA (2004) Genetic consequences of Pleistocene glaciations for the tundra vole (Microtus oeconomus) in Beringia. Mol Ecol 13:135-148

Gortat T, Barkowska M, Gryczyńska-Siemiątkowska A, Pieniążek A, Kozakiewicz A, Kozakiewicz M (2014) The effects of urbanization-small mammal communities in a gradient of human pressure in Warsaw city, Poland. Pol J Ecol 62:163-172

Gray JS, Estrada-Peña A, Zintl A (2019) Vectors of Babesiosis. Annu Rev Entomol 64:149-165

Hamšíková Z, Kazimírová M, Haruštiaková D, Mahríková L, Slovák M, Berthová L, Kocianová E, Schnittger L (2016) Babesia spp. in ticks and wildlife in different habitat types of Slovakia. Parasites Vectors 20:292 
Hasegawa M, Kishino H, Yano T (1985) Dating the human-ape split by a molecular clock of mitochondrial DNA. J Mol Evol 22:160-174

Heglasová I, Rudenko N, Golovchenko M, Zubriková D, Miklisová D, Stanko M (2020) Ticks, fleas and rodent-hosts analyzed for the presence of Borrelia miyamotoi in Slovakia: the first record of Borrelia miyamotoi in a Haemaphysalis inermis tick. Ticks Tick Borne Dis 11:1-7

Hornok S, Flaisz B, Takács N, Kontschán J, Csörgő T, Csipak Á, Jaksa BR, Kováts D (2016) Bird ticks in Hungary reflect western, southern, eastern flyway connections and two genetic lineages of Ixodes frontalis and Haemaphysalis concinna. Parasites Vectors 9:101

Iwasa MA, Kostenko VA, Frisman LV, Kartavtseva IV (2009) Phylogeography of the root vole Microtus oеconomus in Russian Far East: a special reference to comparison between Holarctic and Palearctic voles. Mamm Study 34:123-130

Jia N, Zheng YC, Jiang JF, Jiang RR, Jiang BG, Wei R, Liu HB, Huo QB, Sun Y, Chu YL, Fan H, Chang QC, Yao NN, Zhang WH, Wang H, Guo DH, Fu X, Wang YW, Krause PJ, Song JL, Cao WC (2018) Human babesiosis caused by a Babesia crassa-like pathogen: a case series. Clin Infect Dis 14:1110-1119

Jiang BG, Jia N, Jiang JF, Zheng YC, Chu YL, Jiang RR, Wang YW, Liu HB, Wei R, Zhang WH, Li Y, Xu XW, Ye JL, Yao NN, Liu XJ, Huo QB, Sun Y, Song JL, Liu W, Cao WC (2018) Borrelia miyamotoi infections in humans and ticks, Northeastern China. Emerg Infect Dis 24:236-241

Kahl O, Janetzki C, Gray JS, Stein J, Bauch RJ (1992) Tick infection rates with Borrelia: Ixodes ricinus versus Haemaphysalis concinna and Dermacentor reticulatus in two locations in eastern Germany. Med Vet Entomol 6:363-366

Karbowiak G, Rychlik L, Nowakowski W, Wita I (2005) Natural infections of small mammals with blood parasites on the borderland of boreal and temperate forest zones. Acta Theriol 50:31-42

Kiewra D, Stańczak J, Richter M (2014) Ixodes ricinus ticks (Acari, Ixodidae) as a vector of Borrelia burgdorferi sensu lato and Borrelia miyamotoi in Lower Silesia Poland-Preliminary Study. Ticks Tick Borne Dis 5:892-897

Kiewra D, Czułowska A, Dyczko D, Zieliński R, Plewa-Tutaj K (2019) First record of Haemaphysalis concinna (Acari: Ixodidae) in Lower Silesia, SW Poland. Exp Appl Acarol 77:449-454

Kimura M (1980) A simple method for estimating evolutionary rate of base substitutions through comparative studies of nucleotide sequences. J Mol Evol 16:111-120

Kowalec M, Szewczyk T, Welc-Falęciak R, Siński E, Karbowiak G, Bajer A (2017) Ticks and the cityare there any differences between city parks and natural forests in terms of tick abundance and prevalence of spirochaetes? Parasites Vectors 10:573

Kowalec M, Szewczyk T, Welc-Falęciak R, Siński E, Karbowiak G, Bajer A (2019) Rickettsiales occurrence and co-occurrence in Ixodes ricinus ticks in natural and urban areas. Microb Ecol 77:890-904

Kubiak K, Dziekońska-Rynko J, Szymańska H, Kubiak D, Dmitryjuk M, Dzika E (2019) Questing Ixodes ricinus ticks (Acari, Ixodidae) as a vector of Borrelia burgdorferi sensu lato and Borrelia miyamotoi in an urban area of north-eastern Poland. Exp Appl Acarol 78:113-126

Kumar S, Stecher G, Li M, Knyaz C, Tamura K (2018) MEGA X: molecular evolutionary genetics analysis across computing platforms. Mol Biol Evol 35:1547-1549

Lachmajer J, Skierska B, Wegner Z (1956) Kleszcze rodzaju Haemaphysalis Koch (Ixodidae) znalezione na terenie Polski. Biul Państw Inst Med Morsk Trop J W Gdańsku 7:189-195

Lebedev VS, Bannikova AA, Tesakov AS, Abramson NI (2007) Molecular phylogeny of the genus Alticola (Cricetidae, Rodentia) as inferred from the sequence of the cytochrome b gene. Zool Scr 36:547-563

Liang L, Wang J, Schorter L, Phong T, Trong N, Fell S, Ulrich S, Straubinger RK (2020) Rapid clearance of Borrelia burgdorferi from the blood circulation. Parasites Vectors 13:191

Lissovsky AA, Obolenskaya EV (2011) The structure of craniometrical diversity of grey voles Microtus subgenus Alexandromys. Proc ZIN RAS 315:461-477

Lissovsky AA, Petrova TV, Yatsentyuk SP, Golenishchev FN, Putincev NI, Kartavtseva IV, Sheremetyeva IN, Abramson NI (2018) Multilocus phylogeny and taxonomy of East Asian voles Alexandromys (Rodentia, Arvicolinae). Zool Scr 47:9-20

Lubicz-Niezabitowski E (1933) Klucz do oznaczania zwierząt ssących Polski. Wydawnictwo Koła Przyrodników Uczniów Uniwersytetu Jagiellońskiego. Wydanie drugie całkowicie poprawione i powiększone (In Polish)

Nei M, Kumar S (2000) Molecular evolution and phylogenetics. Oxford University Press, New York

Parola P, Paddock CD, Socolovschi C, Labruna MB, Mediannikov O, Kernif T, Abdad MY, Stenos J, Bitam I, Fournier PE, Raoult D (2013) Update on tick-borne rickettsioses around the world: a geographic approach. Clin Microbiol Rev 26:657-702 
Paziewska A, Zwolińska L, Harris PD, Bajer A, Siński E (2010) Utilisation of rodent species by larvae and nymphs of hard ticks (Ixodidae) in two habitats in NE Poland. Exp App Acarol 50:79-91

Pukhovskaya NM, Morozova OV, Vysochina NP, Belozerova NB, Ivanov LI (2019) Prevalence of Borrelia burgdorferi sensu lato and Borrelia miyamotoi in ixodid ticks in the Far East of Russia. Int J Parasitol Parasites Wildl 6:192-202

Radulović Z, Mihaljica D, Osi N, Penezi A, Aki S, Sukara R, Irovi D, Tomanović S (2017) Hard ticks parasitizing european ground squirrel, Spermophilus citellus (L., 1766) (Rodentia: Sciuridae) in Serbia. Acta Zool Bulg 69:547-554

Rar VA, Epikhina TI, Suntsova OV, Kozlova IV, Lisak OV, Pukhovskaya NM, Vysochina NP, Ivanov LI, Tikunova NV (2014) Genetic variability of Babesia parasites in Haemaphysalis spp. and Ixodes persulcatus ticks in the Baikal region and Far East of Russia. Infect Genet Evol 28:270-275

Rieg S, Schmoldt S, de With TC, K, Wölfel S, Kern WV, Dobler G, (2011) Tick-borne lymphadenopathy (TIBOLA) acquired in Southwestern Germany. BMC Infect Dis 11:167

Rigo K, Gyuranecz M, Toth AG, Földvári G (2011) Detection of Borrelia burgdorferi sensu lato and Anaplasma phagocytophilum in small mammals and ectoparasites in Hungary. Vector Borne Zoonotic Dis 11:1499-2150

Roux V, Rydkina E, Eremeeva M, Raoult D (1997) Citrate synthase gene comparison, a new tool for phylogenetic analysis, and its application for the rickettsiae. Int J Syst Bacteriol 47:252-261

Rubel F, Brugger K, Walter M, Vogelgesang JR, Didyk YM, Fu S, Kahl O (2018) Geographical distribution, climate adaptation and vector competence of the Eurasian hard tick Haemaphysalis concinna. Ticks Tick Borne Dis 9:1080-1089

Rzhetsky A, Nei M (1992) A simple method for estimating and testing minimum evolution trees. Mol Biol Evol 9:945-967

Saitou N, Nei M (1987) The neighbor-joining method: a new method for reconstructing phylogenetic trees. Mol Biol Evol 4:406-425

Stańczak J, Biernat B, Matyjasek A, Racewicz A, Zalewska M, Lewandowska D (2016) Kampinos National Park: a risk area for spotted fever group rickettsioses, central Poland? Exp Appl Acarol 70:395-410

Tamura K, Nei M, Kumar S (2004) Prospects for inferring very large phylogenies by using the neighborjoining method. Proc Natl Acad Sci (USA) 101:11030-11035

Tołkacz K, Bednarska M, Alsarraf M, Dwużnik D, Grzybek M, Welc-Faleciak R, Behnke JM, Bajer A (2017) Prevalence, genetic identity and vertical transmission of Babesia microti in three naturally infected species of vole, Microtus spp. (Cricetidae). Parasites Vectors 10:66

Tomassone L, Portillo A, Nováková M, de Sousa R, Oteo JA (2018) Neglected aspects of tick-borne rickettsioses. Parasites Vectors 11:263

Wang Y, Li S, Wang Z, Zhang L, Cai Y, Liu Q (2019) Prevalence and identification of Borrelia burgdorferi sensu lato genospecies in ticks from Northeastern China. Vector Borne Zoonotic Dis 19:309-315

Welc-Falęciak R, Bajer A, Behnke JM, Siński E (2008) Effects of host diversity and the community composition of hard ticks (Ixodidae) on Babesia microti infection. Int J Med Microbiol 298:235-242

Wodecka B, Rymaszewska A, Sawczuk M, Skotarczak B (2009) Detectability of tick-borne agents DNA in the blood of dogs, undergoing treatment for borreliosis. Ann Agric Environ Med 16:9-14

Zhou X, Xia S, Huang JL, Tambo E, Zhuge HX, Zhou XN (2014) Human babesiosis, an emerging tickborne disease in the People's Republic of China. Parasites Vectors 7:509

Zorenko T, Atanasov NI (2018) Copulatory behavior supports a new insight into taxonomic status of root vole Alexandromys oeconomus (Rodentia, Arvicolinae). Russ J Theriol 17:48-57

Publisher's Note Springer Nature remains neutral with regard to jurisdictional claims in published maps and institutional affiliations. 